\title{
NOTES ON FALSE WIREWORMS WITH ESPECIAL REFERENCE TO ELEODES TRICOSTATA SAY ${ }^{1}$
}

\section{By James W. McColloch, Assistant Entomologist, Kansas State Agricultural Experiment Station}

With the establishment, in 1915, by the Department of Entomology, of project No. 100, dealing with a study of those insects injuring the roots and germinating seeds of staple crops, the writer undertook a study of the available species of the tenebrionid genus Eleodes.

There are two primary reasons why this group of insects was chosen as a part of this project. First, practically nothing is known concerning the life-histories of the various members of this genus. Swenk (1909) partially worked out the life-history of $E$. opaca Say, and Hyslop (1912) gives a short synopsis of the life-history of $E$. letcheri vandykei Blaisd. According to Gebien (1911, pp. 242-252), the genus is a large one, containing 123 species. Eleven of these species have been recorded from Kansas. Second, the beetles of the genus Eleodes are native insects confined principally to the semi-arid regions west of the Mississippi River. In fact, only three species, tricostata, opaca, and suturalis (Wickham, 1899) have been recorded east of Kansas. In Kansas, they are typical of the native prairies and farther west they are found in the sage brush areas. The gradual breaking out of these prairies is depriving these insects of their native food and is forcing them to feed on the more succulent cultivated crops. Just how-successful the different species are in becoming adapted to the new conditions is an interesting problem. E. opaca has already become a serious pest of wheat in Kansas and Nebraska. E. letcheri vandykei has appeared in cultivated fields in the Pacific Northwest, and, in 1913, E. extricata var. convexicollis Blaisd. was found attacking grains in Montana.

The life-histories of several species have now been studied at the Kansas Experiment Station and that of $E$. tricostata will form the basis of this paper. Reference will be made to other members of the genus, especially when they touch on the species under consideration.

\section{Economic Importance of the Genus}

It is only within recent years that the false wireworms have been recognized as pests of growing crops. Blaisdell (1909, p. 29) states

1 Contribution from the Entomological Laboratory, Kansas State Agricultural College, No. 32. This paper embodies some of the results obtained in the prosecution of project No. 100 of the Kansas Experiment Station. 
that as far as he has been able to determine, species of this genus are neither injurious nor beneficial, unless the larvæ are in some way troublesome. Riley (1884, p. 90 ) records the adult of E. quadricollis Esch. injuring the foliage of grapes in California. This species is said to have destroyed 35 acres of grape vines. Bruner (1892, p. 12) found $E$. tricostata injuring cabbages and other garden crops at Lincoln, Nebraska. Swenk (1909, pp. 332-333) gives an account of the serious damage done to planted grain, especially wheat, by $E$. opaca in western Nebraska. Hyslop (1912, p. 75) states that the results of three years' work demonstrate quite conclusively that the false wireworms are among the most destructive insects to recently planted wheat and corn in the Pacific Northwest. E. pimeloides Mann. and $E$. letcheri vandykei are discussed especially in this regard. Webster (1912, p. 32) reports E. sulcipennis Mann. feeding on the larvæ of alfalfa weevil and E. suturalis Say eating chinch bugs. Essig (1915, pp. 290-291) records the adult of $E$. omissa borealis Blaisd. as feeding on the leaves of apricot, orange, plum, and watermelon. Cooley (1916, p. 154) has found E. extricata var. convexicollis Blaisd. very abundant in Montana and in several instances seriously injuring newly sprouted grain.

The above references comprise most of the known reports of the injuries by this genus. That more is not known concerning them is probably due to a number of factors. The larvæ closely resemble the true wireworms and considerable confusion has resulted. Much injury attributed to wireworms, especially in the semi-arid regions, is probably due to the false wireworms. The larvæ are subterranean in their habits and move with great rapidity through the soil, hence it is often impossible to find them at work. The adults are largely nocturnal in their habits, and although they may be extremely numerous in a locality, they are seldom found without a diligent search.

\section{Economic Importance of Eleodes tricostata}

The data on the economic importance of $E$. tricostata are very meager. Wickham (1890, p. 86) states that it feeds on the roots of grasses, and Bruner (1892, p. 12). found it seriously injuring cabbages and other garden crops at Lincoln, Nebraska, and states that it was doing more damage than cutworms. He also says that it is a general feeder upon the prairies and on weeds in the field. Hunter, Pratt, and Mitchell (1912, p. 51) list $E$. tricostata among the insects incidentally associated with the cactus plant.

In Kansas, tricostata appears to be confined almost entirely to the native pastures where the larvæ feed on the roots of the various grasses occurring there. Practically all the adults and larvæ collected in the 
field have been taken in such situations. A few larvæ and adults have been found in wheat and corn fields, but the data thus far collected indicate that this species is a pest of our native prairie grasses. In the laboratory, however, the adults and larvæ feed readily on germinating wheat and corn and there seems to be no reason why this should not occur in nature. The adults also feed freely on young wheat plants growing in the cages.

\section{Distribution}

E. tricostata is one of the more widely distributed species of this genus. Blaisdell (1909, pp. 38 and 107-108) records it from Texas, New Mexico, Oklahoma, Utah, Kansas, Nebraska, Iowa, Idaho, Montana, Colorado, Wyoming, South Dakota, and British America. Say (1823, p. 262) gives the type locality as Missouri and Arkansas. Wickham (1899, p. 60) says it extends as far east as Independence, Iowa, where he found it in September on a broad, dry sand-flat along the Wapsipinicon bottom. Stoner (1913, p. 81) records taking E. tricostata at Fergus Falls, Minnesota, in 1911. This is the first known record of a species of Eleodes being taken in that state. In Kansas, this species is distributed over most of the state. Popenoe $(1877$, p. 36) says that it is common throughout the state and the collection of the Department of Entomology contains specimens from all regions of Kansas except the southeastern part.

\section{Methods of Rearing}

In carrying out the life-history study, the writer found the following methods successful in rearing each of the different stages. Eggs were placed in small vials closed with cotton plugs and kept in the field insectary under outdoor conditions. The larvæ on hatching were placed in one-ounce tin boxes containing slightly moistened soil and a small amount of bran for food. As the larvæ became larger, they were supplied with germinating wheat instead of bran for food. During the summer, it was necessary to change the soil in these boxes about every ten days, but in winter when the larvæ were rather inactive, it was changed about every three weeks. The pupæ were kept in the same boxes in which the transformation took place. The adult beetles were confined in pint fruit jars, containing about an inch of dry soil and a little bran.

With the exception of the eggs, all stages were kept in the cement cave previously described by the writer (1917) where the temperature more nearly approximated subterranean conditions. During the summer months, the temperature of the cave varied from $70^{\circ}$ to $80^{\circ} \mathrm{F}$. With the approach of cold weather, the temperature gradually fell 
until early in March when it was about $40^{\circ} \mathrm{F}$, after which time it began to rise slowly. The results obtained in the life-history work in the cave coincided closely with the field observations made throughout the year.

\section{Description and Life Economy}

THE EGg.-The eggs (Pl. 5, A) of E. tricostata are bluntly oval longitudinally, and circular in diameter. They vary in length from 2.2 $\mathrm{mm}$. to $2.5 \mathrm{~mm}$. and are about $1.2 \mathrm{~mm}$. in diameter. The eggs of this species are much larger than any so far described for the genus. Blaisdell $(1909$, p. 496) states that the eggs of all species of Eleodes which he has examined are about $1 \mathrm{~mm}$. in length. The freshly laid eggs are white in color with no surface markings. As development takes place the color changes to a light creamy yellow.

When deposited, the eggs are coated with a sticky solution which causes a thin layer of dirt to adhere to them, making them hard to find in the field. They are laid singly, although several may be placed in the same cavity. In the rearing cages, the females seemed to prefer dry dirt for oviposition as practically all of the eggs were found in the driest dirt. In oviposition, the female excavates a cavity onefourth inch to three inches in depth and deposits from one to four eggs, after which she fills the hole with dirt.

In hatching, the young larva splits the egg shell at the end and down the side about one-third the way. The larva usually emerges head first but it is not unusual for the reverse to occur. The egg shell appears to be broken by the larva arching the body and this may cause the shell to break at either the anterior or posterior end. When the larva emerges head first, the process requires a very short time, but when it emerges with the posterior end first, several hours may be consumed in emerging, and, in some cases, the larva may be unable to free the head from the shell.

The length of egg stage was determined for 300 eggs in 1915 and 4,800 eggs in 1916. The following table gives the essential data:

Incubation Period

\begin{tabular}{c|c|c|c|c}
\hline \hline Date & $\begin{array}{c}\text { No. Eggs } \\
\text { Hatching }\end{array}$ & Min. Days & Max. Days & Average Days \\
\hline 1915 & 300 & 10 & 30 & $\begin{array}{l}14.5 \\
14.0\end{array}$ \\
\hline
\end{tabular}

The length of the egg stage varies with the season of the year. Eggs laid during July and the first half of August hatched in from 6 to 11 days. After the middle of August the length of the egg stage increased 
rapidly until Novemuer when it was about 46 days. In 1916, the first eggs were deposited on July 10 and the first ones hatched on July 16. The last eggs were laid October 12 .nd the last egg hatched November 20. This gives a period of 133 days that eggs were to be found.

The Larva.- - Very little has been written concerning the larvæ of Eleodes. Gissler $(1878$, p. 19) gives a meager description of the larvæ of $E$. gigantea Mann. and E. dentipes Esch. ]3laisdell (1909, pp. 497499) enlarged on the description of dentipes ar d gives a working basis for the description of the various larvæ of th: genus. Hyslop (1912, pp. 78-81) describes the larvæ of E. letcheri var.dykei and E. pimeloides. In many ways the false wireworms resemble the true wireworms but may be readily distinguished from them by the fact that the antennæ of the Eleodes larva are clavate and longer. T he false wireworms also show a much greater activity than do the true wireworms.

On hatching, the larva ( $\mathrm{Pl} .5, \mathrm{~B}$ ) of E. tricostata is $3.75-4 \mathrm{~mm}$. in length and creamy white in color. After th: first moult, the larva changes to black in color and this color persists, except immediately after moulting, during the rest of this stage. ..n this respect, it differs from any of the described Eleodes larvæ. Wh nn full grown, the larva is about $35 \mathrm{~mm}$. in length.

The larvæ are subterranean in their habits, being found during the summer and fall from one to six inches or more below the surface of the ground. It is not uncommon to find them uniler stones on grass-land but so far the writer has never observed ther 1 on the surface of the ground. They burrow from place to place, feeding on the roots and seeds of plants and probably, to some exten $s$, on decaying organic matter. In the vicinity of Manhattan, the lirvæ appear to be confined to the native grass-land and practically all larvæ found have been taken in such situations. In confinemeat, however, they feed readily on germinating wheat and corn, on bra 1, roots of grasses, and, to some extent, on manure. In addition to this, they often feed on their cast-off skins and on larvæ that have died or are in a weakened condition.

The length of the larval stage was determined for 111 larvæ in 1915 and 1916, these data being summarized in the fullowing table:

Length of Larval Stage

\begin{tabular}{c|c|c|c|c}
\hline \hline Year & No. of Larvæ & Min. Days & M.x. Days & Average Days \\
\hline 1915-1916 & 51 & 252 & $\begin{array}{r}291 \\
332\end{array}$ & $\begin{array}{l}267 \\
292\end{array}$ \\
\hline
\end{tabular}



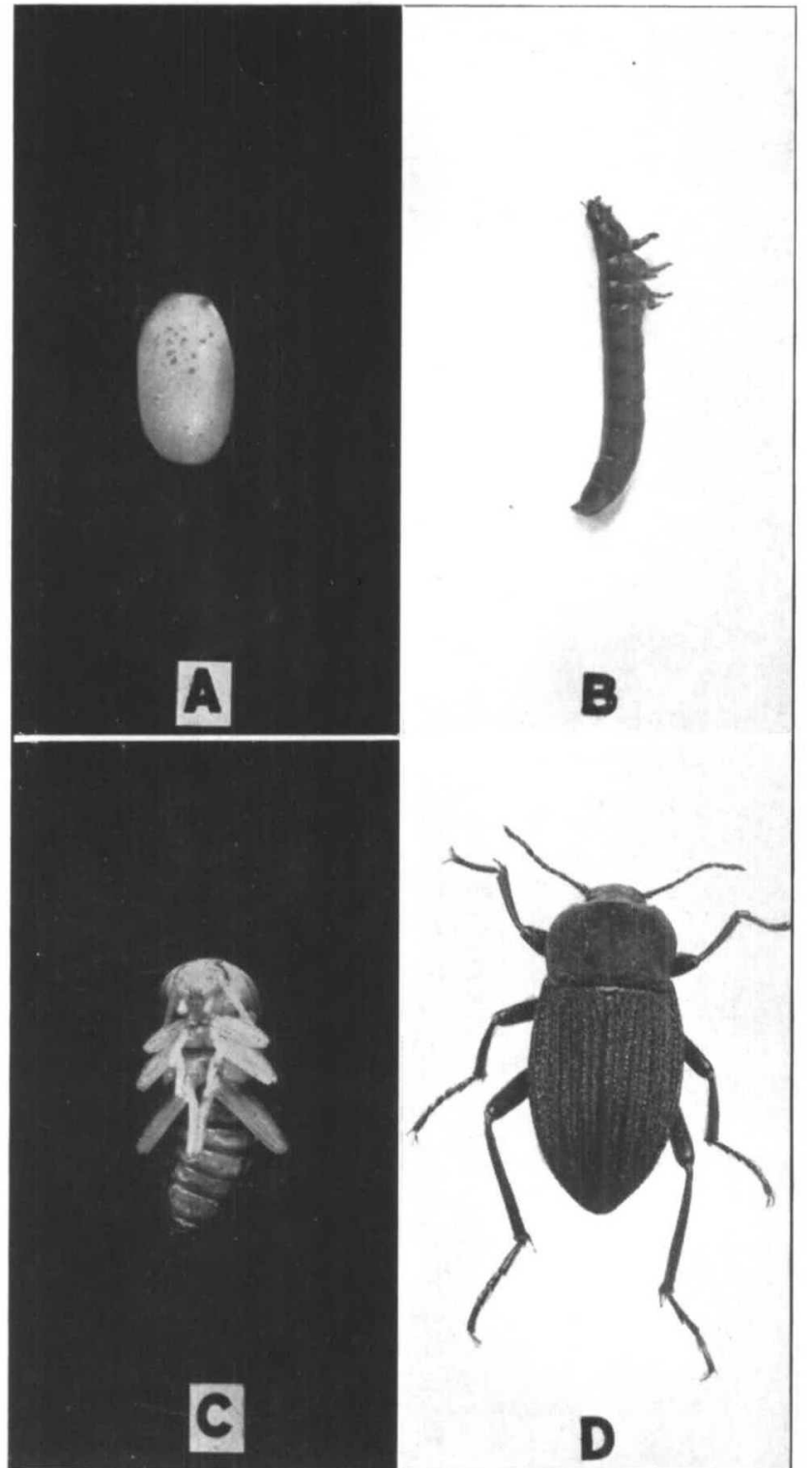

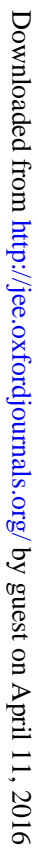

Elfodes tricostata siy. A, egg; B, Jarva; (, pupa; 1), adult. 
Most of the worms reached the next to the last moult during the summer and fall and passed the winter in this condition. From the first of November to the first of March they fed but little and were very inactive. Commencing the first week in March, they began feeding again and moulted during April or May. The first larva pupated May 27 and the last larva on June 30 . Field data bear out this study. Practically full-grown larvæ were found in the grass-land during early April. These moulted and pupated about the same time as those reared. It is interesting to note that five larvæ, hatching from eggs laid early in July, 1916, pupated during October and November. The average length of the larval stage in this case was 77 days. Before pupation, the larve enter a semi-pupal or quiescent stage, which lasts from five to ten days. During this time they do not feed and are very inactive.

In rearing the larvæ, it was found that they made their best growth when placed in boxes containing soil with bran and wheat for food. When fed on decaying matter and roots they made a much slower growth and in nearly every case failed to reach maturity. About 200 larvæ were reared in boxes containing nothing but dry bran. Most of these lived from three to six months but they made very little growth and moulted only once.

The Pupa.-The pupæ (Pl. 5, C) are white in color after transformation and are $15-19 \mathrm{~mm}$. in length. As development proceeds, the body color changes to creamy yellow and the mandibles, legs, and antennæ become dark in color. At the end of 14 to 16 days the mandibles and claws show a deep reddish-brown color.

Pupation took place in the spring of 1916 during the last week in May and the entire month of June. The first larva pupated on May 27 and the last one pupated June 30. Maximum pupation occurred on June 4. The pertinent data on the length of the pupal stage are shown in the following table:

Lengte of Pupal State

\begin{tabular}{c|c|c|c|c}
\hline \hline Year & No. of Pupæ & Min. Days & Max. Days & Average Days \\
\hline 1916 & 49 & 11 & 22 & $\begin{array}{l}19.4 \\
17.0\end{array}$ \\
\hline
\end{tabular}

In one case, a larva pupated October 14,1916 , and the adult issued November 28, giving a pupal stage of 45 days. Another individual pupated October 23, 1916, and passed the winter in this stage, dying in April, 1916.

Thw AddLT.-The adult beetles (Pl. 5, D) are oblong oval, black, 
and clothed with short setiform hairs, each arising from a puncture. Each elytra bears three distinct costæ which are more or less coarsely muricate. The female is robustly oblong, the elytra usually being widest at the middle. A tuft of ordinary piceous spinules occurs on the tip of the first joint of the anterior tarsus; the second joint is unmodified. The male differs from the female in that the body is more oval in shape, the elytra usually being widest at the base. There is a slight modification of the first two segments of the anterior tarsus. The males are $13-20 \mathrm{~mm}$. in length and about $6.5-10.5 \mathrm{~mm}$. in width, while the females are somewhat larger in size, being $14-22 \mathrm{~mm}$. in length and 7-11 mm. in width.

In the life-history studies, adults emerged from the pupal stage June 16 and continued to emerge until July 10 , the maximum emergence occurring about June 24 . Field studies coincide very closely with these results. During the early part of June, it was almost impossible to find adults in the field. Beginning about June 20, however, adults became numerous and most of them were of a bright color and the body soft, showing that emergence had just taken place.

$E$. tricostata may pass the winter as an adult as well as in the larval stage. During March and April of 1916, several adults were found hibernating in spherical cells under rocks. The mortality, however, is very high, varying from 50 to 95 per cent. The writer has never been able to obtain eggs from these overwintering beetles.

While most of the adults emerged before June 24, mating was not observed until July 7 , when it became general in many of the cages and continued until the middle of September. The first eggs were deposited July 10, three days after copulation was noted. Egg laying continued until October 12, at which time the beetles became inactive and appeared to have entered hibernation.

Thirty-one mated females, confined in cages containing about one inch of soil, deposited a total of 5,464 eggs or an average of 176 eggs per female, with extremes of 103 and 262. The largest number of eggs deposited by a single female during a period of 24 hours was 51 . The average period of oviposition for this experiment was 48.8 days, the longest being 75 days and the shortest 24 days. An average of 3.7 eggs were laid on each day. The average number of days on which eggs were laid by each female was 23.6 , with extremes of 11 and 37 days. The average number of eggs laid was 8 .

The proportion of sexes was determined for 1,257 beetles collected in the field during the summers of 1916 and 1917 and the males seemed to predominate, since only 551 of the beetles collected were females while 706 were males. Approximately the same proportion of sexes has prevailed in the rearing work. 
The habits of the beetles have been studied to a limited extent in the field. All of the Eleodes are more or less nocturnal or crepuscular and tricostata is no exception. They may be found abroad early in the morning and towards evening or on cloudy days. During the daytime, however, they are generally found mder rocks, boards, logs and manure where they are rather inactive. Once the cover is removed, however, they run with great rapidity. Feeding, mating, and egg laying take place generally at night, both in the field and in the rearing cages.

The adults have been found feeding in the field on Solidago, Euphorbia marginata, prairie clover, and evening primrose. In the laboratory, they fed on bran and soaked wheat in preference to any other food supplied. They also fed readily on growing wheat plants, especially when the plants were only a few inches high. Some of the beetles fed sparingly on roots and leaves of grasses and on decaying organic matter. They are also cannibalistic to some extent, feeding on dead beetles or those in a weakened condition.

The beetles of $E$. tricostata live for a long period. One female collected early in July, 1915, lived until May, 1916, while many beetles maturing in June, 1916, lived until June and July, 1917. The longest period thus far recorded is for a female that lived 391 days. There seems to be a tendency for the females to live longer than the males. Blaisdell $(1909$, p. 29) records keeping adults of $E$. dentipes alive for over four years.

\section{LENGTH OF LIFE-CYCLE}

The length of the life-cycle normally occupies about one year, Taking the average length of the various stages, it required 328 days from the time the eggs were laid until the adults emerged. In the same way, using the minimum length of each stage, the life-cycle was 85 days, and taking the maximum length of each stage, the life-cycle was 423 days.

\section{Predaceous Enemies}

The members of the genus Eleodes are not preyed upon by a large number of piedaceous enemies. This is probably due to the fact that the adults of most of the species secrete an oily liquid having a strong offensive odor. This is thought to be a protective secretion as it is excreted only when the beetles are disturbed. Gissler (1879) describes the glands which produce this fluid and states that they are found in both sexes. Williston $(1884$, p. 169$)$ says that $E$. tricostata seems to be devoid of these secretions.

Blaisdell (1909, p. 29) says that skunks will feed on Eleodes and that chickens devour them readily as do the ground owls. The butcher 
birds impale them on thorns. Hyslop (1912, p. 84) states that the records of the Bureau of Biological Survey list thirteen species of birds as feeding on the adults of Eleodes. Barrows and Schwarz (1895, p. 64) found Eleodes in the stomach of crows in Kansas and Nebraska, and they state that these betles fulfil most of the requirements of insect food preferred by the crows. Judd $(1898$, p. 25) records the loggerhead strike as feeding on E. tricostata and Beal (1900, p. 70 , and 1911, p. 40) has found specimens of this species in the stomachs of the crow blackbird and the red-headed woodpecker.

\section{Parasites}

Very few parasites have been found attacking any of the Eleodes. Bruner (1892, p. 12) records eggs of a tachinid on the elytra of tricostata and opaca. Riley (1892, pp. 211 and 219) records a braconid parasite, Perilitus sp., from $E$. suturalis. Hyslop (1912, p. 35) found a nematode worm infesting the abdomen of a beetle. He states that the worm nearly filled the abdomen. Ellis (1913, pp. 282-283) describes a gregarine (Stylocephalus giganteus) obtained from E. hispilabris Say and Eleodes sp. During the past summer, the writer found this same gregarine in the alimentary tract of tricostata and opaca. Aldrich (1915, p. 245) reports a Sarcophaga larvipositing on E. tricostata, E. hispilabris, and E. obsoleta Say.

On August 7, 1916, a number of hymenopterous larvæ were found in one of the tricostata cages. On examining the beetles, they were found to be coming out of the anal slit of a male. Shortly after emerging they spun silken cocoons around the edge of the cage and pupated. The adult parasites emerged August 16 and were found to be Perilitus eleodis Viereck. ${ }^{1}$ This same parasite was reared from $E$. opaca on August 23.

A red mite, Trombidium sp., was found on a number of beetles collected July 3, 1917. These mites were attached to the legs and to the various sutures on the ventral side of the body. The beetles were placed in a cage but the mites soon disappeared and none of the beetles died.

A little life-history work was carried on with Perilitus eleodis and it might be of interest to note some of the results obtained. The larva emerge through the anal slit of the beetle and seek a place to pupate. As they move from place to place they leave a trail of silken thread and, where large numbers of larvæ emerged in a cage, the soil was often webbed together. Shortly after emerging the larvæ construct silken

\footnotetext{
1 Determined by Mr. A. B. Gahan, of the Bureau of Entomology, U. S. Department of Agriculture.
} 
cocoons in which they pupate. In spinning these cocoons the soil is webbed together, making it difficult to find them. In the rearing work, the larvæ would not construct cocoons unless there was soil present. The length of the pupal stage was determined for several hundred parasites and was found to range from 8 to 15 days, with an average of 9 days.

On emerging, the adults are rather active but make little effort to fly. On placing the parasites in cages containing adult beetles, they were found remaining close to the ground and apparently trying to get under the beetles. Shortly after introducing parasites into the cages, the beetles became frantic in their movements, running in every direction. The parasites could be observed clinging to the legs of the beetles and were apparently trying to oviposit in the abdominal sutures and at the junction of the legs and body. The parasites did not appear to mind being run over and carried around by the beetles but seemed intent on gaining hold on the ventral side of the abdomen.

Actual oviposition was not definitely observed and, owing to the chitinous integument of the beetle, it was impossible to dissect them and find the eggs. For this reason the length of the egg stage was not determined. The length of the egg and larval stages combined averaged about 12 days, with extremes of 10 and 18 days.

Large numbers of parasites may infest a single beetle, and as high as 124 larvæ were secured from an individual. The average number of parasites bred from a beetle was about 50 . It is interesting to note that the beetles live from 12 to 48 hours after the larvæ leave the body and maintain most of their normal activities up to the time the parasites leave. One female deposited three eggs the same morning that she yielded 124 Perilitus larvæ.

The efficiency of this parasite in the field was not definitely established. In 1916, as high as 50 per cent of the beetles collected in August were parasitized, but, from the data at hand, it would seem that the average parasitism is only about 5 or 7 per cent. Of the 932 beetles collected in 1917, not a single one was parasitized.

\section{Physiological Rerations}

EFFect of Humidity.-Most of the species of the genus Eleodes are confined to the semi-arid regions of the United States west of the Mississippi River. They reach their greatest abundance, both in species and individuals, in those areas of little rainfall. As has been stated elsewhere in this paper, only three species have been authentically recorded east of Kansas. Owing to the wide distribution of $E$. tricostata, however, it is probably not as greatly influenced by moisture conditions as most of the species. 
In the life-history studies, care had to be taken at all times to keep the cages moderately dry. When adults were placed in cages containing moist soil, oviposition decreased, and when they were placed in cages containing both moist and dry soil, they showed a great preference for the dry soil. The larvæ developed best in a slightly moist soil. When the soil was too wet to crumble nicely, the mortality increased greatly.

Blaisdell (1910, pp. 64-65) makes some interesting observations on the effect of moisture on the adults of Eleodes in general. He says that the individuals making up the specific aggregate do not necessarily breed true to any intraspecific degree of sculpturing, as this is wonderfully influenced by environment and food supply. The beetles that develop in an exposed or arid region where the body fluids are reduced to a minimum by evaporation during the latter stages and especially after the pupal skin is shed will have'a comparatively smooth form of sculpturing. Conversely, beetles developing in a protected or moist region where the body fluids are conserved will have a more strongly punctured or strongly striate form. The dominant form of sculpturing is therefore determined by seasonal conditions, a hot, dry season producing a large number of the smooth forms and a cold, wet season the more strongly striate and punctured forms. There will also be a varying per cent of intermediate forms produced.

EFFECT OF Light.-The larvæ of E. tricostata are negatively phototropic. When placed on the surface of the ground they immediately burrow into the soil. In all the studies so far made, larvæ have never been found on the surface of the ground. The adults, like most of the species of Eleodes, are generally nocturnal or crepuscular in their habits. They seek to avoid light in the field by hiding during midday under rocks, logs and manure, and also in burrows of other animals.

\section{Measures of Control}

$E$. tricostata has not as yet become of sufficient economic importance to warrant any extensive experiments on control. The use of poisoned bran was tried, under laboratory conditions, on the adults with good success but the larvæ lived for weeks on such a diet. With most of the injurious forms of Eleodes, it has been found possible to control them by summer fallowing the ground. This is a procedure that could be followed in western Kansas to a good advantage. Rotation is also recommended in some cases since the beetles are wingless and move only on foot. Hyslop (1912, p. 87) records his experience in treating seeds with various poisons to destroy the larvæ. Five or six poisons and repellents were used, all with negative results. 


\section{Literature Cited}

Aldrich, J. M. 1915. The Economic Relations of the Sarcophagida. Jour. ECON. ENT., $8: 242-246$.

Barnows, W. B., and Schwarz, E. A. 1895. The Common Crow of the United States. U. S. Dept. Agr., Div. Ornithology and Mammalogy, Bul. 6, 98 pp.

BesL, F. E. L. 1900. Food of the Bobolink, Blackbirds and Grackles. U. S. Dept. Agr., Div. Biol. Sur., Bul. 13, 77 pp.

1911. Food of the Woodpeckers of the United States. U. S. Dept. Agr., Biol. Sur., Bul. 37, 64 pp.

Blaisdell, F. E. 1909. A Monographic Revision of the Coleoptera Belonging to the Tenebrionid Tribe Eleodini Inhabiting the United States, Lower California, and Adjacent Islands. U. S. Nat. Mus., Bul. 63, 524 pp.

1910. Studies in the Tenebrionid Tribe Eleodiini-Order Coleoptera. Ent. News, 21: 60-67.

BRUNER, L. 1892. Report Upon Insect Depredations in Nebraska for 1891. U. S. Dept. Agr., Div. Ent., Bul. 26 (O.S.), pp. 9-12.

Coolex, R. A. 1916. Insect Pests of 1915. Mont. Agr. Exp. Sta., Bul. 109, pp. 151-154.

Elis, M. M. 1913. A Descriptive List of the Cephaline Gregarines of the New World. Trans. Amer. Micro. Soc., 32: 259-296.

Essia, E. O. 1915. Injurious and Beneficial Insects of California. Monthly Bulletin, Cal. State Comm. Hort., Vol. 4, No. 4, Supplement, 541 pp.

Grbien, H. 1911. Coleopterorum Catalogus. Pars 15, 22, 28, 37: TenebrionidæTrictenotomidæ, pp. 167-354. W. Junk, Berlin.

GissLen, C. F. 1878. On Coleopterous Larvæ of the Family Tenebrionidæ. Bul. Brook. Ent. Soc., 1:18-19.

1879. On the Repugnatorial Glands in Eleodes. Psyche 2: 209-210.

Hunter, W. D., Prate, F. C., and Mrtchell, J. D. 1912. The Principal Cactus Insects of the United States. U. S. Dept. Agr., Bu. Ent., Bul. 113, 71 pp.

HysLoP, J. A. 1912. The False Wireworms of the Pacific Northwest. U. S. Dept. Agr., Bu. Ent., Bul. 95, pt. V, pp. 73-87.

Jodv, S. D. 1898. The Food of Shrikes. U. S. Dept. Agr., Div. Biol. Sur., Bul. 9, pp. 15-26.

McCownoch, J. W. 1917. A Method for the Study of Underground Insects. Jour. ECON. ENT., 10: 183-187.

Popenoe, E. A. 1877. A List of Kansas Coleoptera. Trans. Kan. Acad. Sci,, 5: $21-40$.

Rrwer, C. V. 1884. Grape Pest-Codling Moth. U. S. Dept. Agr., Div. Ent., Bul. 4 (O.S.), p. 90.

1891. A Probable Microgaster Parasite of Eleodes in the Imago State. Proc. Ent. Soc. Wash., 2: 211, 219.

SAY, T. 1823. Descriptions of Coleopterous Insects collected in the late Expedition to the Rocky Mountains, performed by order of Mr. Calhoun, Secretary of War, under the command of Major Long. Jour. Acad. Nat. Sci. Phila., 3: 139-216, 238-282.

Stoner, D. 1913. Eleodes in Minnesota (Coleop.). Ent. News, 24: 81-82.

Swenk, M. H. 1909. Eleodes as an Enemy of Planted Grain. Jour. Econ. Ent., 2: 332-336.

Webster, F. M. 1912. Preliminary Report on the Alfalfa Weevil. U. S. Dept. Agr., Bu. Ent., Bul. 112, 47 pp. 
Wickнам, H. F. 1890. Remarks on Some Western Tenebrionidæ. Ent. Amer., 6: 83-88.

1899. Eleodes in Iowa. Proc. Iowa Acad. Sci., 7: 59-60.

Williston, S. W. 1884. Protective Secretions of Species of Eleodes. Psyche, 4:168-169.

\section{SEASONAL IRREGULARITIES OF THE CODLING MOTH}

\section{By Leroy Chind, Entomologist and Plant Pathologist, Hood River Branch, Oregon Experiment Station}

This paper includes a brief résumé of the observations that have been made relative to the behavior of the codling moth at Hood River, Oregon, during the years 1914, 1915, 1916 and 1917. The work has been conducted for its applicable value chiefly, in order that the local orchardists might be supplied with first hand information on the seasonal progression of this insect's activities, which would enable them to more intelligently and satisfactorily apply their lead sprays. Not being a major project, the investigation lacks many details that would more clearly demonstrate the very wide seasonal variations in the lifehistory of this apple insect from one year to another.

The two most important points that have been brought out in this study are, first, the very decided variation in the emergence of the broods from one season to another and its necessary influence on the timing and applying of sprays in order that control may be entirely successful. Secondly, the investigations indicate that sweeping recommendations given out often in the form of spray bulletins from a central or distant station are far from meeting the requirements in codling moth control in the different apple growing sections of the Pacific Northwest where vast ranges of conditions are found at relatively short distances. These ranges, due probably to temperatures, varying on account of altitudinal, coastal and interior influences, are such as to warrant seasonal studies of the insect in the different sections in order that a comprehensive knowledge of the insect's activities be available for the use of orchardists in their control measures. Until such stations of study are maintained we can expect a great deal of trouble from the codling moth in the Northwest. The variation in the life-history of the moth, which influences the timing of sprays, has been found to be of more importance in the control of the second generation of worms than the first brood, as in the case of the latter, conditions which retard vegetative growth usually directly influence insect activity with a result the standard spring applications-usually a combination insecticide and fungicide-can generally be effectively applied by following a prearranged spraying program. 